\title{
First Case-Control Study of Intestinal Parasites in Follow-up Schizophrenia Patients: Are We Overlooking the Role of These Agents?
}

\author{
Takip Edilen Şizofreni Hastalarında Barsak Parazitleri Araștırılmasındaki illk Olgu \\ Kontrol Çalıșması: Bu Ajanların Rolünü İnceliyor muyuz?

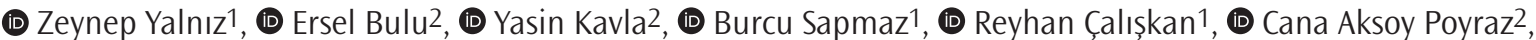 \\ (1) Yaşar Ali Öner1', (1) Ömer Faruk Demirel2, (1) Özer Akgül1
}

${ }^{1}$ Isstanbul Aydın University Faculty of Medicine, Department of Medical Microbiology, İstanbul, Turkey

2istanbul University-Cerrahpaşa, Cerrahpaşa Faculty of Medicine, Department of Psychiatry, İstanbul, Turkey

\begin{abstract}
Introduction: Disability and decrease in the quality of life owing to the nature of schizophrenia are considered factors that predispose patients to parasitic infections. This study aimed to investigate intestinal parasites in schizophrenia and healthy volunteers with similar age-gender data and to contribute to the literature and/or clinical practice by determining the underlying cause of gastrointestinal complaints (such as side effects of psychiatric drugs or overlooked parasitic infection) in patients with schizophrenia.
\end{abstract}

Methods: This case-control study included 30 patients with schizophrenia and 30 healthy volunteers. Their stool samples were examined for the presence of intestinal parasites primarily microscopically or serologically in cases requiring differential diagnosis.

Results: The overall positivity rate of intestinal parasites was $25 \%(15 / 60)$. The difference between the intestinal parasite detection rates, which was $36.7 \%(11 / 30)$ in the schizophrenia group and $13.3 \%(4 / 30)$ in the healthy control group, was significant (odds ratio: 3.76 ; $95 \%$ confidence interval: 1.04 13.65; $p<0.05)$. The distribution of parasite species varied: $6(20 \%)$ patients had Blastocystis spp., 3 (10\%) had Giardia intestinalis (G. intestinalis), and $2(6.7 \%)$ had Entamoeba histolytica in the schizophrenia group, whereas $3(10 \%)$ had Blastocystis spp. and 1 (3.3\%) had G. intestinalis in the healthy control group.

Conclusion: To increase the quality of life of patients with a chronic psychiatric disease such as schizophrenia and to prevent possible transmission, periodic examination of parasitic agents is necessary in addition to psychiatric treatment and further studies are needed.

Keywords: Intestinal parasites, schizophrenia, healthy control

\section{öz}

Amaç: Șizofreninin doğası gereği gözlenen yetiyitimi ve yașam kalitesindeki azalma, sekonder olarak paraziter enfeksiyonlara zemin hazırlayan bir faktör olarak değerlendirilmektedir. Bu olgu-kontrol çalıșmasına, șizofreni tanısı ile takip edilen hastalar ve yaş-cinsiyet verileri benzer sağlıklı gönüllüler dahil edilerek bu olgu grubundaki barsak parazitlerinin araştırılması amaçlanmış̦ır. Ayrıca, şizofreni hastalarındaki gastrointestinal şikayetlerin altta yatan nedeni (psikiyatrik ilaç yan etkisi veya gözden kaçırılan paraziter enfeksiyon varlığı) konusunda bilgi sahibi olunarak literatüre ve/veya klinik pratiğe katkı sağlanması amaçlanmıștır.

Yöntemler: Calıșmaya 30 șizofreni tanılı hasta ve 30 sağ|ıkı gönüllü dahil edilmiş, toplamda 60 olgudan dıșkı örnekleri alınmış ve bu örneklerdeki bağırsak parazitleri öncelikli olarak mikroskobik ayrıcı tanı gereken durumlarda ise serolojik olarak araștırılmışıır.

Bulgular: Calışmada, barsak parazitlerinin genel pozitiflik oranı \%25 (15/60) olarak belirlenmiștir. Şizofreni grubundaki hastalarda \%36,7 (11/30), sağıklı kontrol grubunda \%13,3 (4/30) olarak dağılım gösteren barsak paraziti saptanma oranları arasındaki farkın ise istatistiksel olarak anlamlı olduğu belirlenmiștir (olasılık oranı: 3,76; \%95 güven aralı̆̆ı: 1,0413,65; $p<0,05)$. Sizofreni grubunda 6 olguda (\%20) Blastocystis spp., 3 olguda (\%10) Giardia intestinalis (G. intestinalis) ve 2 olguda $(\% 6,7)$ ise Entamoeba histolytica saptanmış; sağıklı kontrol grubunda ise 3 olguda (\%10) Blastocystis spp. ve 1 olguda $(\% 3,3)$ ise $G$. intestinalis saptanmıştır.

Sonuç: Şizofreni gibi kronik bir psikiyatrik hastalığı olan hastaların yaşam kalitesinin artırıması ve olası bulaşın engellenmesinde psikiyatrik tedavinin yanı sıra paraziter ajanların da periyodik olarak araștııı Iması ve bu konuda daha ileri araștırmalara intiyaç olduğu düșünülmüștür.

Anahtar Kelimeler: Barsak parazitleri, şizofreni, sağ|ıkı kontrol

Address for Correspondence/Yazıșma Adresi: Özer Akgül PhD, İstanbul Aydın University Faculty of Medicine, Department

Cite this article as/Atıf: Yalnız Z, Bulu E, Kavla Y, Sapmaz B, Calıșkan R, Aksoy Poyraz C, Öner YA, Demirel ÖF, Akgül Ö. First Case-Control Study of Intestinal Parasites in Follow-up Schizophrenia Patients: Are We Overlooking the Role of These Agents?. İstanbul Med J 2021; 22(3): 213-7.

(c) Copyright 2021 by the University of Health Sciences Turkey, Istanbul Training and Research Hospital/Istanbul Medical Journal published by Galenos Publishing House

(C) Telif Hakkı 2021 Să̆lık Bilimleri Üniversitesi istanbul Ĕgitim ve Araştırma Hastanesi/Istanbul Tıp Dergisi, Galenos Yayınevi tarafından basılmıștır. 


\section{Introduction}

Schizophrenia is a chronic psychiatric disease with an early onset and variable clinical and related disability. The general prevalence of schizophrenia varies between $1 \%$ and $1.5 \%$, without significant difference between genders in terms of its incidence, but the age of onset is earlier in men than in women (1). In the etiology of schizophrenia, theories related to genetic factors, obstetric anomalies, intrauterine infections, neurodevelopmental, and neurotransmitters are emphasized (2). Pathogens that can manipulate neurotransmitter levels and are therefore defined as neurotrophic microorganisms have been frequently investigated recently to elucidate the etiology of various psychiatric diseases, especially schizophrenia $(3,4)$.

Slow proliferation, ability to escape from the immune system, potential for latent infection, and affinity to the central nervous system are listed as basic characteristics of neurotrophic microorganisms. Among the neurotrophic microorganisms, viruses in the Herpesviridae family (Herpes Simplex virus 1/2, Epstein-Barr virus, and cytomegalovirus), influenza virus, and Toxoplasma gondii, a parasite, are shown as the strongest candidates (5). However, studies investigating the relationship between other medically important parasites and psychiatric diseases have remained quite limited, and the implications of the possible presence of parasitic infection in this patient group have not yet been elucidated.

Parasitic intestinal infections remain an important public health problem in our Turkey, similar to global data. Factors determining the social frequency of parasitic intestinal infections include age, gender, socioeconomic level, education, nutrition, traditions, climatic factors, presence in public areas, and hygienic habits (6). In groups with underlying diseases or need of special care, diagnosis of intestinal parasitic infections gains importance to reduce social transmission and to develop more effective strategies in combating parasitosis (7).

In addition to strengthening this hypothetical approach by investigating the correlation between the pathophysiology of psychiatric disease and microorganisms (8), the investigation of intestinal parasites as comorbid infection agents in patients with psychiatric disorders and disability is underestimated. Increasing the quality of life, preventing possible contamination in hospitalization, which is frequently applied for therapeutic purposes, and providing in-home care in patients who are diagnosed with a chronic psychiatric disease such as schizophrenia due to loss of function (3) are important for both psychiatric clinic and public health.

This study was designed to bridge the research gap in this topic. Patients diagnosed with schizophrenia and healthy volunteers with similar age and gender data were included in this case control study. The presence of intestinal parasites was examined microscopically. ELISA was used in cases where the differential diagnosis was required, and the results obtained were compared with sociodemographic characteristics and disease status.

\section{Methods}

A total of 60 patients (30 patients with schizophrenia and 30 healthy volunteers) between January 2020 and September 2020 were included in this case-control study. The study was approved by the İstanbul Aydın University Non-invasive Clinical Research Ethics Committee (approval number: 2019/128). Written and/or oral informed consent was obtained from all patients.

Thirty patients with schizophrenia living in Istanbul who were followed up in the Department of Psychiatry at istanbul University-Cerrahpaşa, Cerrahpaşa Faculty of Medicine, were included as the first group. The diagnosis of schizophrenia was made according to the Diagnostic and Statistical Manual of Mental Disorders-5 (DSM-5) criteria. The healthy control group consisted of 30 participants without any psychiatric disease or family history according to semi-structured interviews with the Structured Clinical Interview for DSM-5 and having similar age and gender data with the schizophrenia group. Sociodemographic data of all participants were recorded, and participants using antiparasitic drugs were excluded from the study.

Stool samples were taken from the 60 study participants. Stool samples collected were first examined macroscopically and then microscopically. For microscopic examination, Native-Lugol and formol-ethyl acetate concentration methods were used, and the presence of intestinal parasites in the preparations was evaluated microscopically at $10 x$ and 40x magnifications. If parasite identification was unclear in the microscopic examination, these samples were examined by ELISA (Seramun Diagnostica GmbH, Wolzig, Germany), and the parasitological diagnosis was confirmed.

\section{Statistical Analysis}

The number of cases to be included in the study groups was calculated with the $G *$ Power 3.1.9.6 program by taking $\alpha=0.5$ and $\beta=0.20$ so that the power of the test would not be less than $80 \%$. Statistical analysis of the study results was carried out using the IBM SPSS program 26.0 version (IBM Corp., Armonk, NY, USA). Descriptive statistics including tables were used to describe the data. Categorical variables are represented as counts, and frequency distributions were compared with Pearson's chi-square tests. Continuous variables are expressed as median and interquartile range (IQR). Mann-Whitney $U$ test was used to identify differences between groups. To control for confounders that were significant in the univariate analysis, a multiple logistic regression model was employed to investigate the independent association of schizophrenia with intestinal parasites. Odds ratio (OR) along with its 95\% confidence interval $(\mathrm{Cl})$ was used to assess the relationship between dependent and independent variables. The significance limit was accepted as two-tailed at $p<0.05$.

\section{Results}

A total of 60 patients (schizophrenia group, $n=30$; healthy group, $\mathrm{n}=30$ ) were included in this case-control study, and stool samples were examined by microscopic and/or serological methods to detect intestinal parasites.

The median patient age in the schizophrenia group was 37 years (IQR: 47-31) and that in the healthy control group was 40 years (IQR: 46-32), and the two data were comparable (OR: 0.03 ; $95 \%$; $\mathrm{Cl}$ : -0.10 to 0.13 ; $p=0.859)$. There were $10(33.3 \%)$ female and 20 (66.7\%) male patients 
in the schizophrenia group and 11 (36.7\%) female and 19 (63.3\%) male volunteers in the healthy control group, and gender data were evaluated as statistically similar (OR: 1.16; 95\% Cl: 0.40-3.35; $p=0.787$ ). In the schizophrenia group, 24 (80\%) patients were single and $6(20 \%)$ were married; in the healthy control group, 16 (53.3\%) were single and $14(46.7 \%)$ were married, and the difference in the marital status was different (OR: 0.28; 95\% Cl: 0.09-0.90; $\mathrm{p}=0.018$ ). Similarly, the median total duration of education was 8.5 years (IQR: 14-5) in the schizophrenia group and 12 years (IQR: 16-8) in the healthy control group, and the difference was significant (OR: $-0.29 ; 95 \% \mathrm{Cl}$ : -0.58 to $0.00 ; p=0.043$ ). As regards sociodemographic features, the groups demonstrated significant difference in working status. The number of working/nonworking patients in the schizophrenia group was 11 (36.7\%)/19 (63.3\%) and that in the healthy control was $25(83.3 \%) / 5$ (16.7\%), respectively, and the difference was highly significant (OR: 8.64; 95\% Cl: 2.56-29.07; $\mathrm{p}<0.001)$. Comparative sociodemographic data of all cases included in the study are shown in Table 1.

The presence of intestinal parasites in stool samples was examined microscopically and/or serologically. Intestinal parasites were detected in $11(36.7 \%)$ patients in the schizophrenia group, while no parasites were found in 19 (63.3\%) patients. Intestinal parasite was detected in $4(13.3 \%)$ of the volunteers in the healthy control group, while no parasites were detected in 26 (86.7\%). Higher rates of intestinal parasites were detected in the schizophrenia group than in the healthy control group, and the difference was significant (OR: 3.76; 95\% Cl: 1.04-13.66; $\mathrm{p}=0.021$ ). In the multivariate logistic regression analysis, only having a schizophrenia diagnosis had a significant influence on the presence of intestinal parasites (OR: 5.16; 95\% Cl: 1.11-23.97; $p=0.036$ ), and all results are summarized in Table 2.

The distribution of intestinal parasite species that were microscopically detected and serologically confirmed [for Entamoeba histolytica (E. histolytica)/dispar distinction] between groups was determined. No more than one intestinal parasite was detected in the same stool sample in any study participant. In the schizophrenia group, 6 (20\%) participants had Blastocystis spp., 3 (10\%) had Giardia intestinalis (G. intestinalis), and 2 (6.7\%) had E. histolytica. In the healthy control group, Blastocystis spp. was detected in $3(10 \%)$ participants and G. intestinalis in 1 (3.3\%) participant. The distribution of parasite species detected in schizophrenia and healthy control groups is summarized in Table 3.

\section{Discussion}

This case-control study investigated intestinal parasites in patients with schizophrenia undergoing follow-up and compared the results with healthy volunteers. Following literature review, to our knowledge, this is the first study that compared the distribution of intestinal parasites between the schizophrenia group and healthy control group. Primarily, this study found that intestinal parasites were detected more frequently in patients with schizophrenia (36.7\%) than in healthy volunteers (13.3\%), and the difference was significant $(p<0.05)$.

\section{Table 1. Sociodemographic characteristics of the participants}

\begin{tabular}{|l|l|l|l|l|}
\hline & Schizophrenia & Healthy control & Univariate OR (95\% CI) & p-value \\
\hline Age, median, years (IQR) & & $37(47-31)$ & $40(46-32)$ & $0.03(-0.10$ to 0.13$)$ \\
\hline Gender, $n(\%)$ & Female & $10(33.3 \%)$ & $11(36.7 \%)$ & $1.16(0.40-3.35)$ \\
\hline Marital status, $n(\%)$ & Male & $20(66.7 \%)$ & $19(63.3 \%)$ & 0.859 \\
\hline Education median years (IQR) & Single & $24(80 \%)$ & $16(53.3 \%)$ & $0.28(0.09-0.90)$ \\
\hline Employment, $n(\%)$ & Married & $6(20 \%)$ & $14(46.7 \%)$ & $-0.29(-0.58$ to 0.00$)$ \\
\hline IQR: Interquartile range, OR: odds ratio, Cl: confidence interval & & $8.5(14-5)$ & $12(16-8)$ & 0.018 \\
\hline
\end{tabular}

Table 2. Distribution of intestinal parasite presence

\begin{tabular}{|c|c|c|c|c|c|c|c|}
\hline & & Schizophrenia & Healthy control & Univariate $\mathrm{OR}(95 \% \mathrm{Cl})$ & $\mathrm{p}$ & Multivariate OR $(95 \% \mathrm{Cl})$ & p \\
\hline \multirow{2}{*}{ Intestinal parasite, $\mathrm{n}(\%)$} & Negative & $19(63.3 \%)$ & $26(86.7 \%)$ & \multirow{2}{*}{$3.76(1.04-13.66)$} & \multirow{2}{*}{$<0.05$} & \multirow{2}{*}{$5.16(1.11-23.97)$} & \multirow{2}{*}{0.036} \\
\hline & Positive & $11(36.7 \%)$ & $4(13.3 \%)$ & & & & \\
\hline
\end{tabular}

Table 3. Distribution of intestinal parasite species

Intestinal parasite species
Blastocystis spp.
Giardia intestinalis
Entamoeba histolytica
Total

\begin{tabular}{|l|l|}
\hline Schizophrenia, $\mathbf{n}(\%)$ & Healthy control, $\mathbf{n}(\%)$ \\
\hline $6(20 \%)$ & $3(10 \%)$ \\
\hline $3(10 \%)$ & $1(3.3 \%)$ \\
\hline $2(6.7 \%)$ & - \\
\hline $11(36.7 \%)$ & $4(13.3 \%)$ \\
\hline
\end{tabular}


In the study, the most common intestinal parasites in both schizophrenia and healthy control groups were Blastocystis spp. (9). The global prevalence of Blastocystis spp. varies between $1.5 \%$ and $50 \%$, and this proportional difference may be related to bad hygienic habits and development level of patient's geographic location (10). Although its taxonomy, life cycle, and epidemiology are not yet clear, data on the pathogenicity of this parasite, which is widely detected worldwide, are inconsistent. According to current knowledge, if parasite is seen $>5$ times in a microscope field at 40x magnification and no other parasitic/ viral/bacterial agent is detected, it is considered a pathogen, and if the patient experiences clinical signs, parasitism should be treated. Parasitism is still frequently associated with gastrointestinal complaints such as fatigue, anorexia, flatulence, abdominal pain, and diarrhea, which cannot be explained by any other reason (11). Blastocystis spp. was found in 6 (20\%) of 30 patients with schizophrenia and in 3 (10\%) of 30 healthy volunteers. Among the possible reasons for the more frequent detection of the parasites known to be transmitted by the fecal-oral route in the schizophrenia group is poor hygienic habits, which resulted from a lack of self-care.

In this case-control study, the second most common parasite was G. intestinalis. G. intestinalis is one of the most common anterior intestinal parasites among humans worldwide and is transmitted by contaminated water or food (12). Poor living conditions, living in a crowded house or a dirty environment, and having a low socioeconomic status are among other risk factors associated with transmission (13). G. intestinalis infections, which are often asymptomatic in healthy individuals, may lead to varying clinical pictures, ranging from mild diarrhea to severe malabsorption (14). In a study conducted after the water-borne G. intestinalis epidemic in Norway in 2004 (15), cases were examined 5 years after the epidemic, and $54.7 \%$ (29/53) of the cases were reported to have chronic fatigue syndrome due to giardiasis. In addition, the authors emphasized that pathogens such as $G$. intestinalis should be considered in the differential diagnosis of diseases that may have a psychiatric basis such as chronic fatigue syndrome (15). In our study, G. intestinalis was found in $3(10 \%)$ patients in the schizophrenia group and only 1 (3.3\%) in the healthy control group.

In our study, E. histolytica/dispar was detected microscopically in only two patients in the schizophrenia group, and the species distinction in these cases was made by ELISA. Amebiasis is a common parasitic disease caused by E. histolytica (16). Two clinical forms, namely, intestinal and extraintestinal, of clinical amebiasis are caused by E. histolytica present in contaminated water and food (17). E. histolytica amebiasis has varied prevalence worldwide, which varies between $0.4 \%$ and $18.4 \%$ in Turkey (18). Serological and molecular-based diagnostic methods should be applied routinely due to the insufficiency of microscopic methods in the differentiation of pathogenic amoeba species (19). Therefore, in our study, the differential diagnosis of two patients with E. histolytica/dispar was made by ELISA. In this study, E. histolytica was detected in only 2 (6.7\%) patients in the schizophrenia group, and this parasite was not found in any participants in the healthy control group. To our knowledge, our study was the first study that comparatively identified intestinal parasites in patients with schizophrenia and healthy volunteers on a case-control basis. Only one study (20) conducted in Ghana in 2015 partially parallels the general concept of our study. That cross-sectional study included 111 patients in a psychiatric hospital, independent of psychiatric diagnosis, and did not include a healthy control group. Intestinal parasites in the included patients were examined only by microscopic methods. The authors reported that intestinal parasites were detected in $13.5 \%$ (15/111) of the patients, and the most common parasite was E. histolytica/dispar (20). The intestinal parasite detection rate of $13.5 \%$ reported in a previous study (20) was lower than that in our study (36.7\%), and this difference was thought to be due to the study design and limitations reported by the authors.

\section{Study Limitation}

Besides the contribution of our study with preliminary results on the presence of intestinal parasites in patients with schizophrenia, this study has two major limitations that could be addressed in future research. First, this study enrolled a relatively small sample size due to the low compliance of patients with schizophrenia to the nature of this study, which would bias the results toward the null hypothesis. Second, we were unable to evaluate the serological methods for the detection of all intestinal parasites for economic reasons.

\section{Conclusion}

In addition to the pathophysiological/etiological basic enlightenment studies in chronic psychiatric diseases such as schizophrenia, further studies are needed to increase public health and the quality of life of the patient. For further research, it will be possible to reduce confusion for the gastrointestinal symptoms associated with parasitic infections or the side effects of antipsychotic drugs used in the treatment. Thus, this study may have clinical contributions to psychiatric treatment compliance.

Ethics Committee Approval: The study was approved by the İtanbul Aydın University Non-Invasive Clinical Research Ethics Committee (approval number: 2019/128).

Informed Consent: Written and/or oral informed consent was obtained from all patients.

Peer-review: Externally and internally peer-reviewed.

Authorship Contributions: Surgical and Medical Practices - Z.Y., E.B., Y.K., B.S., Y.A.Ö., Ö.F.D., Ö.A.; Concept - Ö.F.D., Ö.A.; Design - Y.A.Ö., Ö.F.D., Ö.A.; Data Collection or Processing - Z.Y., E.B., Y.K., B.S., R.Ç., C.A.P., Ö.F.D., Ö.A.; Analysis or Interpretation - Z.Y., E.B., B.S., R.Ç., Y.A.Ö., Ö.F.D., Ö.A.; Literature Search - Z.Y., E.B., Y.K., B.S., R.Ç., C.A.P.; Writing - Z.Y., E.B., Y.A.Ö., Ö.F.D., Ö.A.

Conflict of Interest: No conflict of interest was declared by the authors.

Financial Disclosure: This work was supported by the Istanbul Aydin University Scientific Research Projects Unit (2020/13).

\section{References}

1. Valton V, Romaniuk L, Douglas Steele J, Lawrie S, Seriès P. Comprehensive review: Computational modelling of schizophrenia. Neurosci Biobehav Rev 2017; 83: 631-46.

2. Khandaker GM, Cousins L, Deakin J, Lennox BR, Yolken R, Jones PB. Inflammation and immunity in schizophrenia: implications for pathophysiology and treatment. Lancet Psychiatry 2015; 2: 258-70. 
3. McGrath J, Saha S, Chant D, Welham J. Schizophrenia: a concise overview of incidence, prevalence, and mortality. Epidemiol Rev 2008; 30: 67-76.

4. Modeling the Psychopathological Dimensions of Schizophrenia From Molecules to Behavior, Eds. Mikhail V. Pletnikov, John L. 1st Edition. Waddington: Handbook of Behavioral Neuroscience, Elsevier; 2016; 23.

5. Akgül Ö, Demirel ÖF. Psychiatry and Microbiology. Savrun BM, eds. Psikiyatri ve Laboratuvar. 1. Baskı. Ankara: Türkiye Klinikleri; 2020. p. 47-50.

6. Jong E. Intestinal parasites. Prim Care 2002; 29: 857-77.

7. Suntaravitun P, Dokmaikaw A. Prevalence of Intestinal Parasites and Associated Risk Factors for Infection among Rural Communities of Chachoengsao Province, Thailand. Korean J Parasitol 2018; 56: 33-9.

8. Torrey EF, Bartko JJ, Yolken RH. Toxoplasma gondii and other risk factors for schizophrenia: an update. Schizophr Bull 2012; 38: 642-7.

9. Ustün \$, Turgay N. Blastocystis hominis and bowel diseases. Turkiye Parazitol Derg 2006; 30: 73-7.

10. Kumarasamy V, Anbazhagan D, Subramaniyan V, Vellasamy S. Blastocystis sp., Parasite Associated with Gastrointestinal Disorders: An Overview of its Pathogenesis, Immune Modulation and Therapeutic Strategies. Curr Pharm Des 2018; 24: 3172-5.

11. Scanlan PD. Blastocystis: past pitfalls and future perspectives. Trends Parasitol 2012; 28: 327-34.

12. Yılmaz A, Uslu H. Examination of Giardia intestinalis with Direct Microscopy and Direct Fluorescent Antibody in Patients with Diarrhea. Turkiye Parazitol Derg 2020; 44: 187-90.
13. Einarsson E, Ma'ayeh S, Svärd SG. An up-date on Giardia and giardiasis. Curr Opin Microbiol 2016; 34: 47-52.

14. Allain T, Buret AG. Pathogenesis and post-infectious complications in giardiasis. Adv Parasitol 2020; 107: 173-99.

15. Mørch K, Hanevik K, Rivenes AC, Bødtker JE, Næss H, Stubhaug B, et al. Chronic fatigue syndrome 5 years after giardiasis: differential diagnoses, characteristics and natural course. BMC Gastroenterol 2013; 13: 28.

16. Tüzemen NÜ, Doğan N. Comparison of direct microscopy, culture, ELISA and molecular methods for diagnosis of Entamoeba histolytica. Mikrobiyol Bul 2014; 48: 114-22.

17. Ralston KS. Taking a bite: Amoebic trogocytosis in Entamoeba histolytica and beyond. Curr Opin Microbiol 2015; 28: 26-35.

18. Tanyuksel M, Yilmaz H, Ulukanligil M, Araz E, Cicek M, Koru O, et al. Comparison of two methods (microscopy and enzyme-linked immunosorbent assay) for the diagnosis of amebiasis. Exp Parasitol 2005; 110: 322-6.

19. Fotedar R, Stark D, Beebe N, Marriott D, Ellis J, Harkness J. Laboratory diagnostic techniques for Entamoeba species. Clin Microbiol Rev 2007; 20 : 511-32.

20. Duedu KO, Karikari YA, Attah SK, Ayeh-Kumi PF. Prevalence of intestinal parasites among patients of a Ghanaian psychiatry hospital. BMC Res Notes 2015; 8: 651. 